\title{
STUDI EKSPERIMEN KONVERSI LPG PADA SEPEDA MOTOR BERBAHAN BAKAR BENSIN
}

\author{
Yusup Nur Rohmat \\ Staf Pengajar Jurusan Teknik Mesin Politeknik Negeri Indramayu \\ J1. Lohbener Lama No. 08 Indramayu, 45252 \\ E-mail : yusupnurrohmat@gmail.com
}

\begin{abstract}
Abstrak
Tingginya pertumbuhan jumlah kendaraan bermotor serta konsumsi bahan bakar minyak di Indonesia telah menimbulkan masalah terhadap lingkungan dan penyedian bahan bakar ini. Selain itu subsidi untuk pengadaannya sangat memberatkan Anggaran Pendapatan dan Belanja Negara. Oleh karena itu harus terus dilakukan upaya komprehensif untuk mencari solusi terbaiknya. Dalam makalah ini dibahas hasil penelitian yang bertujuan untuk mengurangi emisi dan menurunkan konsumsi bahan bakar sepeda motor, dengan mengkonversi penggunaan bahan bakar bensin dengan LPG yang biasa digunakan untuk memasak. Pengujian dilakukan di laboratorium menggunakan dinamometer chassis untuk membandingkan torsi, daya, tingkat konsumsi bahan bakar serta biaya operasi, pada sebuah mesin sepeda motor berkarburator menggunakan bahan bakar bensin dan LPG, baik tanpa pengubahan kondisi pengapian maupun dengan mengubah kondisi pengapian. Dari penelitian ini didapatkan bahwa bahan bakar LPG memiliki unjuk kerja yang baik dan dapat digunakan secara langsung tanpa mengubah kondisi pengapiannya. Akan tetapi kinerjanya akan lebih baik jika kondisi pengapiannya disesuaikan. Tingkat konsumsi terbaik LPG adalah $86 \mathrm{~km} / \mathrm{kg}$ atau senilai Rp.58/km sedangkan bensin $66 \mathrm{~km} / \mathrm{l}$ atau Rp. $98 / \mathrm{km}$.
\end{abstract}

Kata Kunci: $L P G$, bensin, kinerja, emisi, konversi

\section{PENDAHULUAN}

Penggunaan bahan bakar minyak (BBM) untuk transportasi menimbulkan masalah pencemaran udara terutama di kota- kota besar yang tingkat kepadatan kendaraannya cukup tinggi. Sub sektor transportasi jalan menjadi penyumbang besar zat-zat pencemar akibat pembakaran bahan bakar minyak seperti NOx, $\mathrm{CO}, \mathrm{CO}_{2}$ yang menjadi bahan yang menyebabkan pemanasan global. Efek pemanasan global telah dirasakan di banyak bagian dunia berupa naiknya temperatur global yang menyebabkan berubahnya pola iklim dan cuaca dunia. Selain itu, pembakaran bahan bakar minyak oleh kendaraan bermotor juga menghasilkan zat pencemar lain yang sangat berbahaya bagi kesehatan manusia seperti senyawa timbal, merkuri, partikel asap, maupun uap bahan bakar minyak. Dikhawatirkan, jika tingkat emisi seperti sekarang ini terus berlangsung keadaan akan semakin parah.

Pemerintah Indonesia telah berkomitmen padapertemuan kelompok G-20 di Pittsburg, Amerika Serikat dan COP 15 UNFCCC di Kopenhagen tahun 2009, untuk menurunkan tingkat emisi karbon sebesar 26\% (atau 767 juta ton karbon) pada tahun 2020. Bahkan, kalau ada bantuan dari negara-negara maju, Indonesia siap mengurangi hingga $41 \%$. Untuk mencapai target tersebut maka telah dikeluarkan Peraturan Presiden Nomor 61 Tahun 2011 tentang
Rencana Aksi Nasional Penurunan Emisi Gas Rumah Kaca. Dalam Perpres tersebut dinyatakan bahwa RANGRK merupakan pedoman bagi Kementerian dan lembaga untuk melakukan perencanaan, pelaksanaan, serta monitoring dan evaluasi rencana aksi penurunan emisi GRK, dan juga sebagai pedoman bagi Pemerintah daerah dalam penyusunan RAN- GRK. Di dalamnya juga sudah dirinci tugas dan target penurunan emisi yang harus dicapai oleh kementerian atau lembaga terkait, termasuk rencana biaya untuk pelaksanaannya.

Selain pencemaran lingkungan, penggunaan BBM pada kendaraan bermotor di Indonesia juga dihadapkan pada masalah makin tingginya volume impor serta tingginya beban biaya subsidi bahan bakar ini, yang kian memberatkan Anggaran Pendapatan dan Belanja Negara. Pada tahun 2011, peranan bahan bakar minyak dalam konsumsi energi final di Indonesia mencapai $47,6 \%$ dari seluruh konsumsi energi, dimana sektor transportasi menyerap 37,68\% dari seluruh konsumsi energi final. Sektor transportasi mengkonsumsi bahan bakar minyak sebesar 45,77 juta kilo liter atau 72,7\% dari seluruh konsumsi BBM di Indonesia. Adapun sektor transportasi darat menyerap $91 \%$ dari seluruh konsumsi BBM sektor transportasi, atau 66,2\% dari seluruh konsumsi BBM di Indonesia [1]. Dengan nilai realisasi subsidi BBM pada tahun 2011 sebesar 41,8 
juta kilo liter atau sebesar 142,92 triliun rupiah [2] maka sektor transportasi jalan menjadi salah satu pemakai anggaran negara terbesar.

Sebenarnya telah banyak regulasi dan kebijakan yang dibuat oleh pemerintah Indonesia terkait dengan masalah emisi dan penyediaan bahan bakar minyak ini. Akan tetapi aspek pelaksanaannya sangat lemah sehingga permasalahan tersebut masih juga belum jelas pemecahannya. Hal ini disebabkan karena permasalahan ini menyangkut berbagai kepentingan, baik secara ekonomi, sosial, politik, dan budaya. Bahkan, ada beberapa kebijakan yang dianggap saling berlawanan, misalnya pemberian insentif pembebasan pajak barang mewah bagi beberapa jenis kendaraan yang justru memperbesar jumlah subsidi bahan bakar. Namun demikian, seharusnya semua pihak, baik pemerintah, kalangan pengusaha, dan masyarakat harus memiliki kesadaran akan pentingnya pemecahan masalah tersebut, karena pada akhirnya akan berdampak kepada aspek ketahanan nasional.

Pada dasarnya, penurunan kuantitas emisi gas buang kendaraan bermotor sebanding dengan penurunan tingkat konsumsi bahan bakar, atau peningkatan efisiensi kendaraan bermotor. Bahkan pada umumnya peningkatan efisiensi ini juga sebanding dengan peningkatan kualitas emisi gas buang. Oleh karena itu, salah satu cara untuk memecahkan dampak penggunaan bahan bakar minyak pada kendaraan bermotor adalah dengan meningkatkan efisiensi kendaraan. Cara ini dapat ditempuh dengan meningkatkan efisiensi kendaraan yang diproduksi oleh pabrik kendaraan, dan juga dengan mengendarai kendaraan secara efisien, seperti yang diterapkan pada metoda Smart Driving (Nazaruddin Sinaga, 2013). Metoda lain yang dapat ditempuh untuk mengatasi dampak penggunaan bahan bakar minyak adalah dengan melakukan diversifikasi sumber energi, misalnya dengan menggunakan bahan bakar gas, biosolar, alkohol, dan listrik.

Penggunaan bahan akar gas dapat dilakukan baik secara individual maupun dalam bentuk campuran (dual fuel). Saat ini bahan bakar yang banyak digunakan sebagai subtitusi bahan bakar minyak adalah CNG (Compressed Natural Gas) dan LPG (Liquified Petroleum Gas). Implementasi bahan bakar gas CNG (disebut dengan BBG) untuk kendaraan bermotor di Indonesia sebenarnya sudah dimulai sejak lama, akan tetapi kuantitasnya hingga kini masih relatif sangat kecil, terutama digunakan pada armada bus Trans Jakarta dan kendaraan roda tiga di DKI Jakarta. Kendaraan lain, seperti taxi, bus swasta, dan kendaraan pribadi masih enggan menggunakannya karena ada masalah teknis dalam pengisiannya. Selain itu terdapat juga persepsi masyarakat yang keliru terhadap tingkat keamanan penggunaan BBG sebagai bahan bakar kendaran bermotor.

Penggunaan bahan bakar LPG, atau dikenal dengan LGV (Liquid Gas for Vehicle) di Indonesia dapat dikatakan masih belum dikenal, meskipun beberapa tahun lalu pernah dicoba untuk disosialisasikan oleh pemerintah. Sosialisasi ini tidak menarik minat masyarakat dikarenakan harganya yang hampir sama dengan harga bensin premium. Di samping itu, juga diperlukan seperangkat alat yang cukup mahal untuk pengubahan bahan bakar mesin, yang disebut dengan Converter Kit. Oleh karena itu, jika pemerintah mau melakukan kaji ulang untuk menentukan harga yang lebih menarik, dan membantu dalam penyediaan infra struktur dan pengadaan converter kit yang murah, maka sebenarnya penggunaan bahan bakar LPG cukup potensial sebagai salah satu solusi untuk menurunkan emisi gas buang dan menurunkan ketergantungan terhadap bahan bakar minyak.

Penggunaan LPG sebagai bahan bakar kendaraan sepeda motor di Indonesia diperkirakan cukup menarik, mengingat jumlah sepeda motor saat ini cukup banyak yaitu lebih dari 80 juta unit [3]. Namun demikian sebelumnya perlu dilakukan kajian mendalam terhadap berbagai aspek yang menyertainya, misalnya perancangan dan pembuatan converter kit, sistem tangki bahan bakar, sistem pengisian bahan bakar, sistem operasi kendaraan serta kinerja mesin. Oleh karena itu dalam penelitian akan dipelajari kemungkinan penggunaan LPG pada sepeda motor secara langsung dengan menggunakan kondisi pengapian yang sudah diset oleh pabrik pembuat sepeda motor (engine map standar) dan juga untuk kondisi pengapian yang dimodifikasi (engine map modifikasi). Parameter yang diamati dalam penelitian ini adalah jenis bahan bakar, yaitu bensin premium, pertamax, pertamax plus dsn gas LPG, serta torsi, daya, konsumsi bahan bakar dan biaya operasi. Adapun tujuan akhir dari penelitian ini adalah untuk mempersiapkan sebuah prototipe sistem konversi bahan bakar LPG dari suatu sepeda motor sistem karburator lengkap dengan teknik modifikasi kondisi pengapiannya.

\section{METODE}

Sesuai dengan tujuan yang disebutkan di atas maka penelitian ini melibatkan studi literatur, observasi lapangan dan kaji eksperimental. Studi literatur terutama bertujuan untuk mempelajari teori pembakaran pada motor bakar torak bersistem karburator dengan bahan bakar bensin atau LPG. Aspek kondisi pengapian terhadap torsi, daya dan konsumsi bahan bakar dipelajari untuk mengetahui efeknya 
terhadap kemungkinan penerapan. Observasi lapangan dilakukan untuk mengetahui sejauh mana penggunaan bahan bakar sebagai bahan bakar telah dilakukan di Indonesia, baik untuk sepeda motor maupun mobil, selain juga untuk mengetahui pendapat masyarakat terhadap kemungkinan penggunaan LPG sebagai bahan bakar sepeda motor. Selanjutnya dilakukan beberapa uji eksperimental untuk mengetahui pengaruh kondisi pengapian dan jenis bahan bakar terhadap torsi, daya, dan konsumsi bahan bakar.

Pengujian eksperimental yang dimulai dengan persiapan bahan dan alat ukur. Pada tahap ini awalnya digunakan sebuah converter kit yang diimpor dari Tiongkok. Akan tetapi karena dijumpai beberapa kekurangan dalam pengaturan debit bahan bakar maka dibuat pula sebuah converter kit yang lebih baik kinerjanya. Untuk pengujian ini digunakan bahan bakar LPG produksi PT Pertamina ukuran tabung $3 \mathrm{~kg}$ yang biasa digunakan untuk memasak. Untuk penyaluran bahan bakar digunakan selang gas tekanan tinggi yang dilengkapi dengan regulator, pengukur tekanan, dan pengatur debit gas dan tekanan vakum. Seluruh pengujian dilakukan di atas sebuah chassis dinamometer yang dapat digunakan untuk mengukur putaran mesin, torsi, dan daya keluaran pada roda kendaraan. Selain itu, dinamometer ini digunakan untuk mengukur konsumsi bahan bakar dengan menggunakan metoda pengujian standar UN-ECE. Untuk menjamin ketelitian dalam pengukuran konsumsi bahan bakar maka digunakan dua alat ukur yang berbeda, yaitu pengukuran volume, untuk bahan bakar bensin, dan pengukuran massa untuk bahan bakar gas. Seluruh alat ukur yang digunakan dalam pengujian ini terlebih dahulu dikalibrasi. Sepeda motor yang digunakan adalah sepeda motor Honda Revo 110 CC yang telah dipakai sejauh $8000 \mathrm{~km}$ yang terlebih dahulu diganti oli dan di-tune up. Dalam penelitian ini tidak dilakukan pengujian kandungan dan sifat-sifat bahan bakar. Data sifat-sifat bahan bakar diperoleh dari literatur dan peraturan Dirjen Migas. Untuk menjaga konsistensi sifat LPG maka pembelian LPG dilakukan di agen penjualan yang sama.

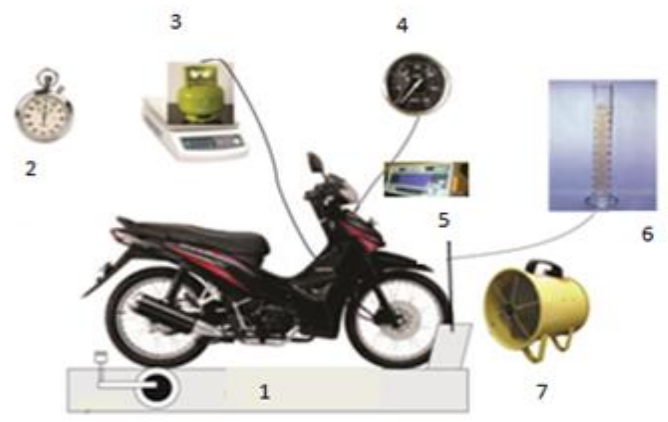

Pada Gambar 1 diperlihatkan skema sistem pengukuran, dimana: (1) chassis dinamometer, (2) stopwatch, (3) gas dan timbangan, (4) tachometer engine, (5) torsimeter dan tachometer rol dinamometer, (6) alat ukur konsumsi bensin, (7) blower pendingin mesin. Adapun spesifikasi utama mesin sepeda motor adalah sebagai berikut:

Jumlahsilinder : : lbuah

Volume langkah $\quad: 110 \mathrm{cc}$

Perbandingan Kompresi : $9,0: 1$

Dayamaksimum $\quad: 8,46 \mathrm{Hppada} 7500 \mathrm{rpm}$

Torsi maksimum $\quad: 8,6 \mathrm{Nm}$ pada 5500rpm

Sistem pengapian $\quad:$ CDI

Dalam penelitian ini pengukuran engine map dilakukan dengan menggunakan sebuah timing light, yang dapat menunjukkan nilai saat pengapian dan putaran mesin. Adapun pembuatan engine map modifikasi dilakukan dengan menggunakan sebuah $C D I$ Programmable yang dapat diatur saat pengapiannya melalui sebuah program komputer. Pengukuran torsi dan daya mesin dilakukan dengan menggunakan sebuah alat ukur yang dirancang secara khusus untuk keperluan tersebut. Metoda pengukurannya adalah menggunakan metoda absorpsi daya pengereman yang divariasikan nilainya pada kecepatan konstan. Untuk mendapatkan engine map modifikasi dilakukan dengan memvariasikan sudut pengapian terhadap kecepatan putar mesin dan posisi throttle.

\section{HASIL DAN PEMBAHASAN 3.1 Engine Map Standar}

Hasil pengukuran terhadap engine map standar diperlihatkan pada Gambar 2 di bawah. Dari gambar tersebut terlihat bahwa perubahan saat pengapian terjadi cukup cepat antara putaran mesin stasioner dan 4000 rpm, setelah itu perubahannya relatif kecil. Pada sepeda motor ini saat penyalaan stasioner berada sekitar 11 derajat sebelum Titik Mati Atas (TMA), sedangkan pada putaran tinggi sudut pengapiannya 27 derajat sebelum TMA. Engine map seperti ini biasanya diterapkan untuk sebuah mesin yang bekerja secara moderat, dimana daya dan torsi yang dihasilkan tidak terlalu besar karena mempertimbangkan tingkat konsumsi bahan bakar yang rendah. Bentuk diagram engine map yang dihasilkan dari pengukuran ini juga dikonfirmasi oleh beberapa bengkel sepeda motor yang ada di Semarang.

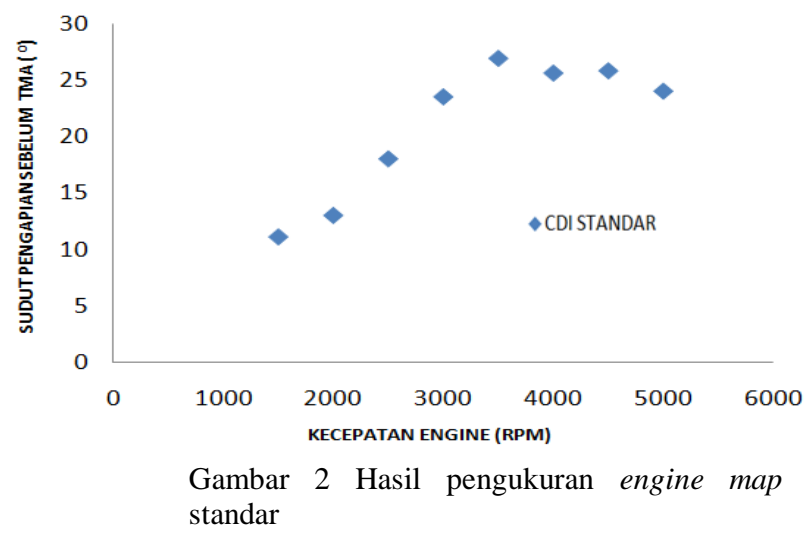




\subsection{Torsi dan Daya pada Engine Map Standar}

Perbandingan torsi yang dihasilkan olen mesin sepeda motor yang menggunakan berbagai bahan bakar dengan engine map standar ditunjukkan pada Gambar 3. Selanjutnya pada Gambar 4 diperlihatkan pada perbandingan daya. Dari kedua gambar tersebut terlihat bahwa torsi dan daya yang dihasilkan mesin sepeda motor tidak terlalu dipengaruhi oleh jenis bahan bakar yang digunakan. Namun demikian masih dapat diamati bahwa secara umum torsi yang dihasilkan oleh bahan bakar LPG lebih rendah daripada bahan bakar lainnya. Hal ini dapat dipahami karena nilai kalor bahan bakar bensin persatuan massa adalah lebih besar dibandingkan dengan nilai kalor bahan bakar LPG [4]. Selain itu, karena engine map yang digunakan adalah engine map standar, maka kelebihan dari sifat LPG yang memiliki angka oktan yang tinggi belum dirasakan efeknya. Penjelasan yang sama juga dapat diberlakukan pada pengaruh jenis bahan bakar terhadap daya yang dihasilkan oleh mesin sepeda motor.

Perlu dijelaskan disini bahwa sebenarnya rasio udara bahan bakar (AFR) juga sangat mempengaruhi daya dan torsi yang dihasilkan mesin. Di dalam penelitian ini nilai AFR diatur sedemikian sehingga proses pembakaran selalu berada dalam keadaan miskin dimana terdapat udara berlebih untuk menjamin terbakarnya bahan bakar. Pengaturan AFR yang tinggi ini dapat dengan mudah di lakukan baik ketika menggunakan karburator atau ketika menggunakan konverter kit. Selama pengujian ini, pemantauan terhadap nilai AFR ini dilakukan dengan menggunakan gas analyzer.

\subsection{Konsumsi Bahan Bakar pada Engine Map Standar}

Pada penelitian ini dilakukan 2 cara pengukuran konsumsi bahan bakar. Cara pertama dilakukan untuk mengetahui pengaruh jenis bahan bakar terhadap konsumsi bahan bakar pada berbagai kecepatan putar mesin. Hasil pengukuran dengan cara ini diperlihatkan pada Gambar 5. Dari gambar ini terlihat bahwa konsumsi bahan bakar LPG secara konsisten selalu lebih rendah daripada bahan bakar lainnya.

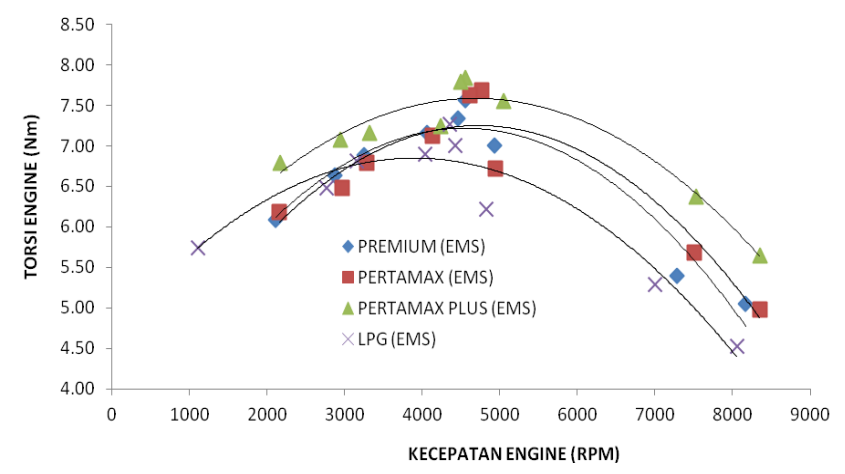

Gambar 3 Perbandingan torsi yang dihasilkan pada engine map standar

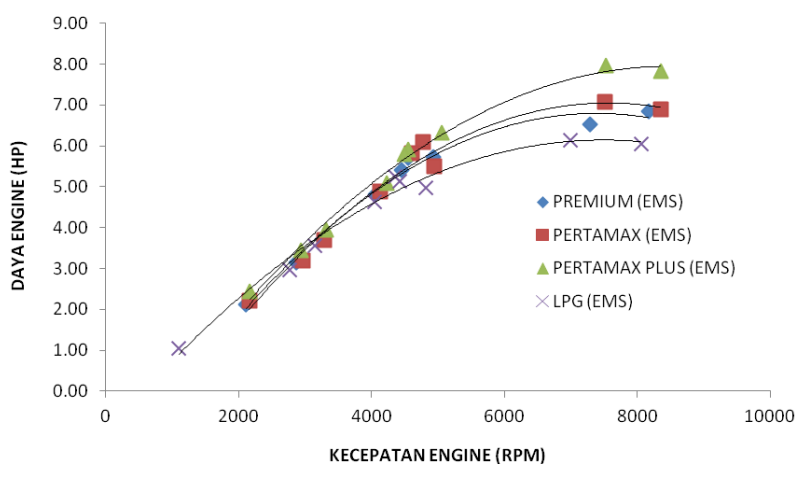

Gambar 4 Perbandingan daya yang dihasilkan pada engine map standar

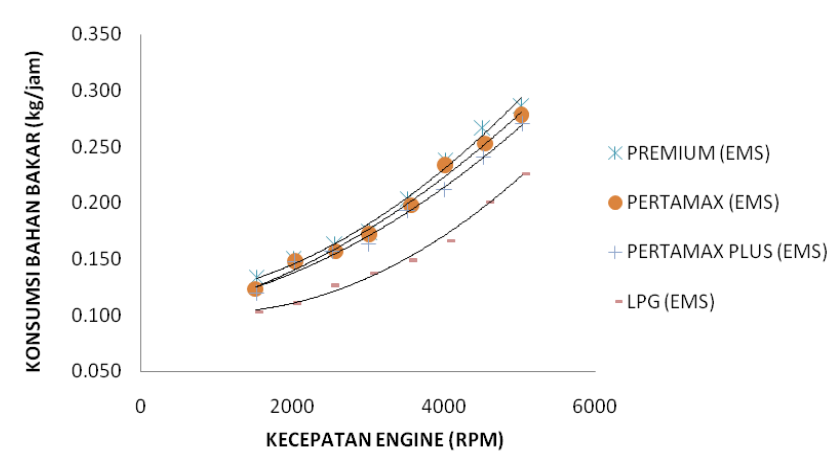

Gambar 5 Perbandingan konsumsi bahan bakar pada engine map standar

Perbedaannya juga cukup signifikan yaitu sekitar $14 \%$ jika dibandingkan antara bahan bakar LPG dan bensin. Mengapa bahan bakar LPG lebih rendah pada tingkat konsumsinya dibandingkan dengan bahan bakar bensin diduga karena LPG mempunyai sifat campuran gas-udara lebih mudah terbakar dan merambat di dalam ruang bakar. Di samping itu juga disebabkan karena proses reaksi kimia pembakaran gas LPG memiliki nilai kecepatan reaksi yang lebih tinggi dibandingkan dengan bensin.Pengukuran cara kedua yang dilakukan terhadap konsumsi bahan bakar adalah menggunakan driving cycle standar UN-ECE. Pada prinsipnya standar ini dibuat untuk merepresentasikan kondisi pengoperasian kendaraan di jalan raya oleh seorang pengemudi normal. Dengan menggunakan standar ini maka pengukuran konsumsi bahan bakar (dalam satuan $\mathrm{km} /$ liter) dapat dilakukan di laboratorium dengan menggunakan chasis dinamometer. Hasil pengukuran konsumsi bahan bakar menggunakan driving cycle ini ditunjukkan pada Tabel 1 di bawah. Dari tabel tersebut jelas terlihat bahwa tingkat konsumsi bahan bakar gas (dalam satuan $\mathrm{km} / \mathrm{kg}$ ) selalu lebih rendah daripada bahan bakar lainnya. Hal ini mengindikasikan bahwa efisiensi volumetrik proses pembakaran bahan bakar LPG adalah lebih tinggi dibandingkan dengan bahan bakar lainnya. Tingginya efisiensi volumetrik bahan bakar LPG disebabkan karena lebih tingginya nilai oktan bahan bakar LPG dibandingkan bahan bakar lainnya [4]. 
Tabel 1. Perbandingan konsumsi bahan bakar pada engine map standar

\begin{tabular}{llcccc}
\hline No & Jenis bahan bakar & $\begin{array}{c}\text { Satuan } \\
(\mathrm{Kg}, \text { Liter })\end{array}$ & $\begin{array}{c}\text { Harga } \\
(\mathrm{Rp})\end{array}$ & $\begin{array}{c}\text { Jarak tempuh } \\
(\mathrm{km})\end{array}$ & $\begin{array}{c}\text { Biaya } \\
(\mathrm{Rpp} / \mathrm{km})\end{array}$ \\
\hline 1 & Premium & Liter & 6500 & 66,38 & 97,92 \\
2 & Pertamax & Liter & 11050 & 71,12 & 155,37 \\
3 & Pertamax plus & Liter & 12650 & 76,59 & 165,17 \\
4 & LPG & $\mathrm{Kg}$ & 5000 & 86,12 & 58,06 \\
\hline
\end{tabular}

\subsection{Engine MapModifikasi}

Pembuatan engine map modifikasi dimaksudkan untuk menyesuaikan antara saat penyalaan bahan bakar terhadap sifat dari bahan bakar, terutama angka oktannya. Dengan menyesuaikan saat penyalaan tersebut diharapkan kinerja yang lebih baik untuk masing- masing bahan bakar. Dalam penelitian ini teknik penentuan saat penyalaan dilakukan secara trial and error dengan mengacu kepada engine map standar. Kriteria utama yang digunakan untuk menentukan engine map modifikasi ini adalah tingkat konsumsi bahan bakar yang minimum. Adapun pengubahan saat penyalaan ini dilakukan dengan menggunakan CDI Programmable yang dapat dibeli di pasaran. Berdasarkan analisis data yang cukup banyak dan memakan waktu yanag lama maka dihasilkan engine map modifikasi yang memberikan tingkat konsumsi bahan bakar yang lebih rendah. Kurva engine map modifikasi untuk bahan bakar LPG diperlihatkan pada gambar . Dari gambar tersebut terlihat bahwa engine map modifikasi ini kisarannya lebih luas dari pada engine map standar. Hal ini cukup menarik untuk diteliti lebih lanjut, mengingat bahwa angka oktan bahan bakar LPG lebih tinggi dari pada angka oktan bahan bakar bensin. Secara teknik seharusnya saat penyalaan LPG bisa dibuat lebih dekat dengan dengan TMA. Kondisi ini bisa dimengerti karena pada penentuan engine map modifikasi tersebut kriterianya adalah konsumsi bahan bakar terendah, bukan torsi atau daya tertinggi.

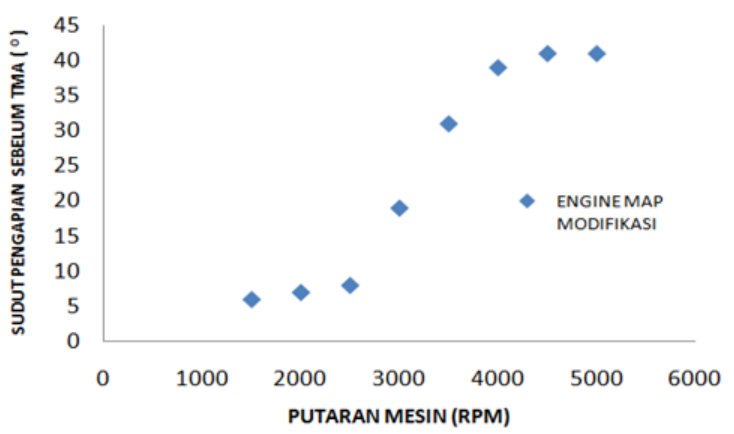

Gambar 6 Engine map modifikasi bahan bakar LPG

\subsection{Torsi dan Daya pada Engine Map Modifikasi}

Pada pengujian atau perbandingan untuk pengujian torsi dan daya pada gambar 7 dan 8 secara berturut- turut diperlihatkan bahwa perbandingan torsi dan daya terhadap jenis bahan bakar yang digunakan pada pengujian engine map modifikasi. Dari kedua gambar pada pengujian grafik tersebut dapat dilihat bahwa torsi dan daya yang dihasilkan oleh bahan bakar LPG secara umum adalah lebih rendah dari pada bahan bakar bensin. Hal ini disebabkan karena nilai kalor pembakaran LPG adalah lebih rendah dibandingkan dengan bahan bakar bensin [5]. Meski demikian, jika dibandingkan dengan kondisi engine map standar, torsi dan daya yang dihasilkan oleh bahan bakar LPG tidak mengalami peningkatan yang berarti, seperti ditunjukkan pada Gambar 9. Hal ini sekali lagi dalam penelitian pengujian ini dapat dijelaskan bahwa pada kondisi engine map modifikasi ini kriteria pada pembuatan engine map didasarkan pada tingkat konsumsi bahan bakar paling minimum atau kondisi yang hemat bahan bakar.

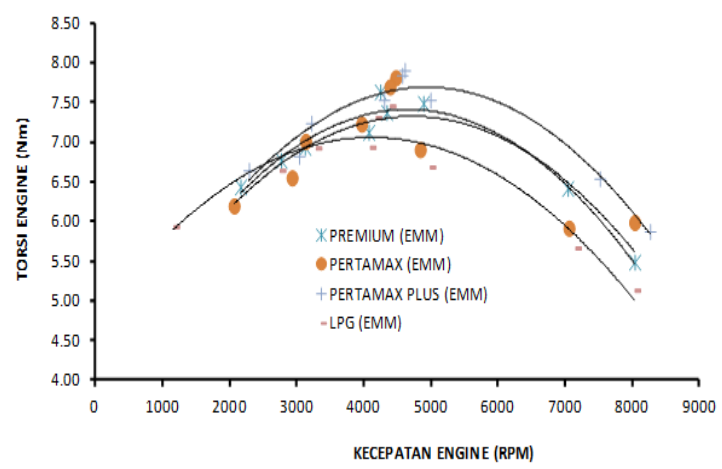

Gambar 7 Perbandingan torsi pada engine map modifikasi

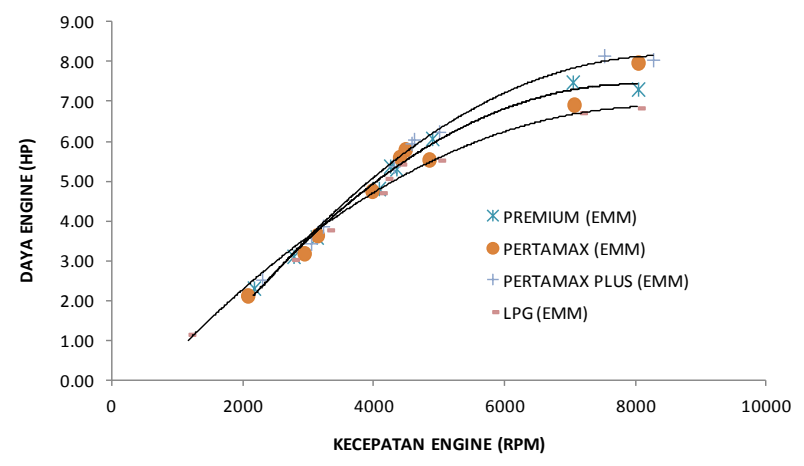

Gambar 8 Perbandingan daya pada engine map modifikasi

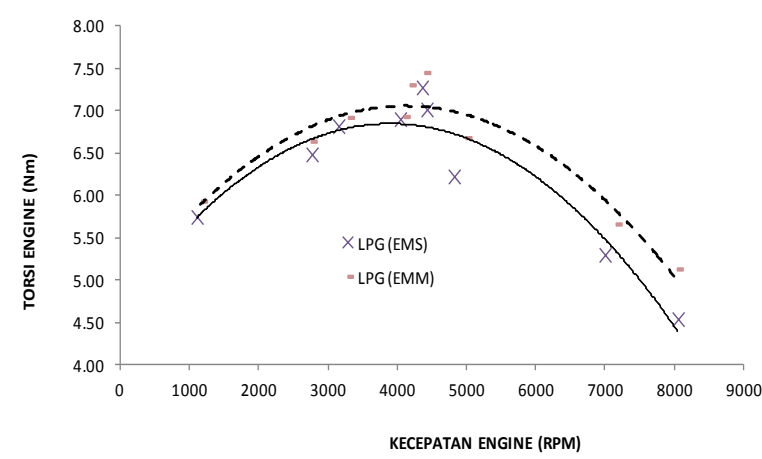

Gambar 9 Perbandingan torsi bahan bakar LPG pada engine map standar dan modifikasi 


\subsection{Konsumsi Bahan Bakar pada Engine Map Modifikasi}

Seperti telah diduga sebelumnya, ternyata penerapan engine map modifikasi dapat menurunkan tingkat konsumsi bahan bakar secara signifikan. Hal ini dapat diamati, baik untuk berbagai bahan bakar bensin maupun bahan bakar LPG. Hasil pengukuran konsumsi bahan bakar menggunakan Driving Cycle UN-ECE ditunjukkan pada Tabel 2. Pada tabel tersebut juga dapat dilihat perbedaan tingkat konsumsi bahan bakar antara engine map standar dan engine map modifikasi. Penurunan tingkat konsumsi bahan bakar yang tidak disertai dengan penurunan torsi dan daya menunjukkan bahwa engine map modifikasi yang dihasilkan dari penelitian ini lebih baik dibandingkan dengan engine map standar pabrik pembuat sepeda motor. Hasil ini sekaligus memberi indikasi bahwa penggunaan bahan bakar LPG secara teknis berpotensi untuk mensubstitusi bahan bakar bensin pada sepeda motor sistem karburator.

Tabel 2 Perbandingan konsumsi bahan bakar metoda menggunakan engine map modifikasi

\begin{tabular}{llcccc}
\hline No & Jenis bahan bakar & $\begin{array}{c}\text { Satuan } \\
(\mathrm{Kg}, \text { Liter })\end{array}$ & $\begin{array}{c}\text { Harga } \\
(\mathrm{Rp})\end{array}$ & $\begin{array}{c}\text { Jarak tempuh } \\
(\mathrm{km})\end{array}$ & $\begin{array}{c}\text { Biaya } \\
(\mathrm{Rp} / \mathrm{km})\end{array}$ \\
\hline 1 & Premium & Liter & 6500 & 76,59 & 84,87 \\
2 & Pertamax & Liter & 11050 & 82,97 & 133,18 \\
3 & Pertamax plus & Liter & 12650 & 86,58 & 146,11 \\
4 & LPG & Kg & 5000 & 95,38 & 52,42 \\
\hline
\end{tabular}

Hasil penelitian ini menunjukkan bahwa secara teknis penggunaan bahan bakar LPG dapat secara langsung diterapkan tanpa harus mengubah engine map mesin sepeda motor. Hal ini dapat disimpulkan berdasarkan unjuk kerja mesin, yang dirpetesentasikan oleh nilai torsi, daya dan konsumsi bahan bakar. Jika dihitung berdasarkan harga bahan bakar bersubsidi bensin premium, yaitu Rp.6500/kg dan harga gas Elpiji tabung $3 \mathrm{~kg}$ bersubsidi, yaitu Rp.5000/kg maka biaya operasi bahan bakar bensin adalah Rp.98/km sedangkan biaya operasi menggunakan gas Elpiji sebesar Rp.58/km. Perbedaan biaya transportasi ini sangat besar, yaitu mencapai $69 \%$. Hal ini tentu sangat menarik untuk dikaji lebih lanjut mengingat potensinya yang sangat baik untuk menurunkan konsumsi bahan bakar secara nasional, yang selain menghemat biaya transportasi pemilik kendaraan, juga dapat menurunkan biaya subsidi bahan bakar minyak.

Selain keuntungan ekonomi yang diperoleh dari pemanfaatan LPG sebagai bahan bakar kendaraan bermotor, penggunaan bahan bakar ini tentu mengurangi emisi gas buang kendaraan bermotor, baik kualitas maupun kuantitasnya. Hal ini disebabkan karena jumlah bahan bakar yang dibakar persatuan jarak tempuh makin berkurang, disamping menurunnya kadar CO dan HC dari emisi gas buang. Namun demikian, penelitian ini perlu diperdalam dengan mengamati efek- efek negatif yang mungkin ditimbulkan, misalnya temperatur blok mesin, kehandalan komponen mesin, aspek keselamatan dan juga kemudahan pengisian bahan bakar LPG. Penulis sangat yakin, jika pemerintah memiliki tekad, komitmen dan upaya yang kuat dalam mengelola energi di tanah air ini, maka bangsa Indonesia dapat menjadi negara yang mandiri dan memiliki ketahanan yang kuat di bidang energi.

Untuk menggunakan LPG sebagai bahan bakar pengganti bensin diperlukan tangki gas dan converter kit yang murah tetapi handal dan memenuhi syaratsyarat keselamatan. Khusus untuk sepeda motor, sebenarnya converter kit ini dapat dibuat dengan harga yang murah dan terjangkau oleh masyarakat pemilik sepeda motor. Tangki gas LPG harus dibuat kuat, aman, dan menarik. Masalah lain yang perlu dipikirkan adalah sistem pengisian LPG ke dalam tangki sepeda motor. Jika pengisiannya tidak mengandalkan stasiun pengisian bahan bakar gas, yang memerlukan biaya pengadaan yang cukup besar, maka dapat ditempuh model pengisian dari tangki ke tangki. Pengisian dengan metoda ini sangat murah namun memerlukan sebuah pompa khusus yang harus dipikirkan rancangannya.

\section{PENUTUP \\ Kesimpulan}

Pada makalah ini telah diuraikan hasil penelitian pengaruh penggunaan bahan bakar dan engine map terhadap torsi, daya, konsumsi bahan bakar dan biaya operasi bahan bakar pada sebuah sepeda motor sistem karburator 4 tak. Kesimpulan utama yang yang didapatkan dari penelitian ini adalah bahwa bahan bakar LPG dapat diterapkan langsung menggantikan bahan bakar bensin tanpa harus mengubah engine map. Selain itu disimpulkan pula bahwa penerapan engine map yang dimodifikasi dapat menurunkan tingkat konsumsi bahan bakar tanpa mengalami penurunan torsi dan daya mesin. Kesimpulan penting lainnya adalah bahwa secara umum penggunaan bahan bakar LPG bersubsidi sangat berpotensi untuk mengatasi masalah emisi gas buang dan ketergantungan terhadap bahan bakar minyak untuk kendaran bermotor.

\section{Saran}

Berdasarkan penelitian yang telah dilakukan, penulis menyarankan beberapa hal yang mungkin bisa menjadi masukan untuk pengembangan penelitian lebih lanjut sebagai berikut:

a. Perlu dilakukan penelitian lebih lanjut untuk desain converter kit yang lebih sederhana dan murah harganya.

b. Perlu dilakukan penelitian untuk mencari engine map modifikasi untuk beberapa merk atau tipe sepeda motor. 


\section{Ucapan Terima Kasih}

1. Lab. EECL (Eficiency\& Energy Conservation Laboratory) Undip Semarang.

2. Lab. Jurusan Teknik Mesin Politeknik Negeri Indramayu.

3. Semua pihak yang telah turut serta memberikan bantuan, dorongan serta masukan demi selesainya penelitian ini.

\section{DAFTAR PUSTAKA}

\section{A. Artikel Seminar}

[1] Legowo, E., 2012, "Kebijakan Pengaturan BBM Bersubsidi, Workshop IIEE, GSI \& IISD, Pengendalian BBM Bersubsidi: Persiapan Implementasi dan Mitigasi Dampak Negatifnya", Jakarta.

[2] Sinaga, N., 2013, "Hubungan antara Posisi Throttle, Putaran Mesin dan Posisi Gigi terhadap Konsumsi Bahan Bakar pada Beberapa Kendaraan Penumpang”, Universitas Diponegoro.

[3] Morganti, K., J., 2013, "The Research and Motor Octane Numbers of Liquefied Petroleum $\operatorname{Gas}(L P G)$ ", University of Melbourne, Australia.

\section{B.Handbook/manual}

[1] Kementerian ESDM, 2013, "Handbook of Energy \& Economic Statistics of Indonesia 2012", Jakarta.

[2] Heywood, J.B., 1988, "Internal Combustion Engine Fundamentals”, Massachusetts Institute of Technology.

[3] Guzzella, L., Sciarretta, A., 2007, "Vehicle Propulsion Systems", Springer-Verlag Berlin Heidelberg. 